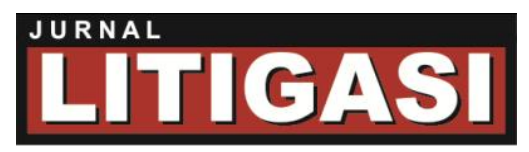

Available online at: http://ejournal.unpas.ac.id/index.php/litigasi

Litigasi, Vol. 17(1), 2016, 3221-3255

DOI: http://dx.doi.org/10.23969/litigasi.v17i1.46

\title{
KEBIJAKAN PENEGAKAN HUKUM TERHADAP PEREMPUAN KORBAN KEKERASAN DALAM RUMAH TANGGA
}

\section{Susi Delmiati}

Program Studi PPKn STKIP YDB Lubuk Alung Jl. Pulau Jantung Indah Lubuk Alung, Telp: (0751) 96079, Hp: 085281097999, E-mail: susidelmiati@gmail.com.

\begin{abstract}
ABSTRAK
Kekerasan adalah perilaku atau perbuatan yang terjadi dalam relasi antar manusia, baik individu maupun kelompok, yang dirasa oleh salah satu pihak sebagai satu situasi yang membebani, membuat berat, tidak menyenangkan, tidak bebas. Situasi yang disebabkan oleh tindak kekerasan ini membuat pihak lain sakit, baik secara fisik maupun psikis serta rohani. Perempuan dalam hal ini sering menjadi korban kekerasan baik itu korban dari suatu kejahatan yang dilakukan oleh penjahat maupun yang dilakukan oleh orang-orang terdekat seperti keluarga maupun dari keluarga dekat/kerabat dekat. Untuk tegak atau berjalannya perlindungan hukum terhadap perempuan korban kekerasan dalam rumah tangga diperlukan penegakan hukum yang jelas. Dalam penegakan hukum tersebut ada beberapa faktor yang mempengaruhinya antara lain: Faktor hukumnya sendiri, faktor penegak hukum, faktor sarana dan fasilitas faktor masyarakat dan faktor budaya.
\end{abstract}

Kata Kunci: Kekerasan, Perlindungan, Perempuan.

\begin{abstract}
Violence refers to behavior deviation occurring in human relationship, whether individual or group, which is burdening, unpleasant and unfair. The effect of the violence should be physically, psychologically and spiritually painful. Woman in this case is mostly the victim of the domestic violence carried out by immediate relatives. Thus, legal protection has to be explicitly initiated that women who experience the domestic violence can be protected. There are some factors determined the legal protection, namely legal factors, legal upholder factors, legal facilities factors, community and cultural factors.
\end{abstract}

Keywords: Violence, Protection, Women.

Copyright @ 2016 , LITIGASI, p-ISSN: 0853-7100; e-ISSN: 2442-2274 
Available online at: http://ejournal.unpas.ac.id/index.php/litigasi

Litigasi, Vol. 17(1), 2016, 3221-3255

DOI: http://dx.doi.org/10.23969/litigasi.v17i1.46

\section{PENDAHULUAN}

Negara Indonesia adalah Negara Hukum sebagaimana yang

tercantumkan dalam Pasal 1 ayat (3) UUD 1945. Negara hukum dimaksud adalah negara yang menegakan supremasi hukum untuk menegakan kebenaran dan keadilan dan tidak ada kekuasaan yang tidak dipertanggungjawabkan. (MPR, 210:46). Prinsip penting dalam negara hukum adalah perlindungan yang sama (equal protection) atau persamaan dalam hukum (equality before the law). Perbedaan perlakuan hukum hanya boleh jika ada alasan yang khusus, misalnya, anak-anak yang dibawah umur 17 tahun mempunyai hak yang berbeda dengan anak-anak yang diatas 17 tahun. Perbedaan ini ada alasan yang rasional. Tetapi perbedaan perlakuan tidak dibolehkan jika tanpa alasan yang logis, misalnya, karena warna kulit, gender, agama dan kepercayaan, sekte tertentu dalam agama, atau perbedaan status seperti antar tuan tanah dan petani miskin. Meskipun demikian, perbedaan perlakuaan tanpa alasan yang logis seperti sampai saat ini masih banyak terjadi di berbagai negara, termasuk di negara yang hukumnya sudah maju sekalipun (Munir Fuady 2009:207).

Negara yang menganut paham negara hukum berlaku prinsip-prinsip pokok Negara Hukum, (Scheltema dalam B. Arief Sidharta 2004:124-125). Prinsip-prinsip Negara hukum antara lain mengatur tentang perlindungan terhadap hak asasi manusia. Perlindungan terhadap hak asasi manusia diatur di dalam undang-undang, baik di dalam Undang-Undang Dasar 1945 maupun

Copyright @ C 2016, LITIGASI, p-ISSN: 0853-7100; e-ISSN: 2442-2274 
undang-undang yang mengatur khusus tentang hak asasi manusia. Hak asasi manusia merupakan hak dasar yang melekat pada diri manusia dari sejak dalam kandungan. Oleh karena itu wajib untuk dihormati, dilindungi serta mendapat perlakuan hukum yang adil serta mendapat perlakuan yang sama di depan hukum (UU No. 39 tahun 1999 tentang Hak Asasi Manusia).

Hal ini juga diatur dalam Undang-Undang Dasar 1945 Pasal 28 G ayat (1) yang menyatakan bahwa: "Setiap orang berhak atas perlindungan diri pribadi, keluarga, kehormatan, martabat, dan harta benda yang berada di bawah kekuasaannya,serta berhak atas rasa aman dan perlindungan dari ancaman ketakutan untuk berbuat atau tidak berbuat sesuatu yang merupakan hak asasi". Selanjutnya Pasal $28 H$ ayat (2) Undang-Undang Dasar 1945 juga menyatakan bahwa, "Setiap orang berhak mendapatkan kemudahan dan perlakuan khusus untuk memperoleh kesempatan dan manfaat yang sama guna mencapai persamaan dan keadialan.

Hal yang paling fundamental dalam prinsip kesetaraan dari hak asasi manusia adalah meletakkan orang terlahir bebas dan memiliki kesetaraan dalam hak asasi manusia, sedangkan prinsip pelanggaran diskriminasi adalah bagian penting dari prinsip kesetaraan. Sedangkan kewajiban positif untuk melindungi hak-hak tertentu, suatu negara tidak boleh mengabaikan hak-hak dan kebebasankebebasan. Sebaliknya negara memiliki kewajiban positif untuk melindungi secara aktif dan memastikan terpenuhinya hak-hak dan kebebasan-kebebasan (Jack Donely, 2008:11).

Copyright @ C 2016, LITIGASI, p-ISSN: 0853-7100; e-ISSN: 2442-2274 
Available online at: http://ejournal.unpas.ac.id/index.php/litigasi

Litigasi, Vol. 17(1), 2016, 3221-3255

DOI: http://dx.doi.org/10.23969/litigasi.v17i1.46

Diskriminasi terhadap perempuan dapat diartikan sebagai setiap pembedaan, pengucilan, atau pembatasan yang dibuat atas dasar jenis kelamin, yang bertujuan atau berpengaruh untuk menghalangi, meniadakan pengakuan terhadap dinikmatinya atau dilaksanakannya hak asasi manusia dan kebebasan dasar oleh kaum perempuan (Schuler dan Thomas, 2001:46). Perempuan dalam hal ini sering menjadi korban kekerasan baik itu korban dari suatu kejahatan yang dilakukan oleh penjahat maupun yang dilakukan oleh orang-orang terdekat seperti keluarga maupun dari keluarga dekat/kerabat dekat.

Kekerasan adalah perilaku atau perbuatan yang terjadi dalam relasi antar manusia, baik individu maupun kelompok, yang dirasa oleh salah satu pihak sebagai satu situasi yang membebani, membuat berat, tidak menyenangkan, tidak bebas. Situasi yang disebabkan oleh tindak kekerasan ini membuat pihak lain sakit, baik secara fisik maupun psikis serta rohani. Kekerasan dalam rumah tangga merupakan salah satu dari berbagai macam bentuk tindak pidana kekerasan yang telah teridentifikasi dalam masyarakat internasional. PBB mendefinisikan istilah kekerasan terhadap kekerasan terhadap perempuan pada deklarasi tahun 1993 sebagai semua tindakan kekerasan berdasarkan gender (maksudnya atas dasar pertimbangan gender) yang mengakibatkan kerugian/bahaya/melukai secara fisik, sexual,psikologi maupun penderitaan kepada perempuan, termasuk pula tindakan mengancam, kekerasan, perampasan secara sewenang-wenang terhadap kebebasan, apakah itu terjadi di ranah public maupun kehidupan pribadi (any act of gender-based violence that result in, or is

Copyright @ 2016 , LITIGASI, p-ISSN: 0853-7100; e-ISSN: 2442-2274 
likely to result in, physical, sexual or psychological harm or suffering to women, including threat of such acts, coercion or arbitrary deprivation of liberty, whether occurring in public or private life) (Andre Vesa dalam Aroma Elmina Martha, 2013:1).

Konsideran Undang-Undang No. 23 Tahun 2004 tentang Penghapusan Kekerasan Dalam Rumah Tangga butir a, b dan $c$ menjelaskan bahwa setiap warga negara berhak mendapat rasa aman dari segala bentuk kekerasan. Ratna Batara Munti (dalam Novianty Djafri, 2008:246), menjelaskan bahwa ;

Kekerasan terhadap perempuan dalam rumah tangga dapat terjadi dalam berbagai bentuk sebagaimana diringkaskan di bawah ini yaitu: 1) Kekerasan fisik langsung dalam bentuk pemukulan, pencakaran sampai pengrusakan vagina (kekerasan seksual) dan kekerasan fisik secara tidak langsung yang biasanya berupa memukul meja, membanting pintu, memecahkan piring, gelas, tempat bunga dan lainlain, serta berlaku kasar. 2) Kekerasan psikologis, berupa ucapan kasar, jorok, dan yang berkonotasi meremehkan dan menghina, mendiamkan, menteror baik secara langsung maupun menggunakan media tertentu, berselingkuh, dan meninggalkan pergi tanpa kejelasan dalam waktu lama dan tanpa tanggung jawab. 3) Kekerasan ekonomi, berupa tidak diberikannya nafkah selama perkawinan atau membatasi nafkah secara sewenang-wenang, membiarkan atau bahkan memaksa istri bekerja keras, juga tidak memberi nafkah setelah terjadi perceraian meskipun pengadilan memutuskan. 4) Gabungan dari berbagai kekerasan sebagaimana disebutkan di atas baik fisik, psikologis, maupun ekonomis.

Sebelum disahkannya Undang-Undang No. 23 tahun 2004 tentang Penghapusan Kekerasan Dalam Rumah Tangga (PKDRT) dalam banyak kasus kekerasan yang terjadi pada umumnya para pelakunya terkena ancaman hukum berdasarkan Pasal 351 KUHP (penganiayaan), Pasal 352 KUHP (penganiayaan 
Available online at: http://ejournal.unpas.ac.id/index.php/litigasi

Litigasi, Vol. 17(1), 2016, 3221-3255

DOI: http://dx.doi.org/10.23969/litigasi.v17i1.46

ringan), Pasal 353 KUHP (penganiayaan yang direncanakan), Pasal 354 KUHP (penganiayaan berat), Pasal 355 KUHP (penganiayaan berat yang direncanakan), jika perbuatan tersebut dilakukan kepada ibunya, bapaknya menurut undangundang, isterinya atau anaknya maka ancaman hukuman ditambah dengan sepertiga. Ketentuan di atas meskipun memang tidak secara khusus mengatur tentang kekerasan dalam rumah tangga, tapi setidaknya dapat digunakan untuk mengadukan para pelaku ke kepolisian dan bahkan KUHP memberikan ancaman hukuman lebih berat jika penganiayaan itu dilakukan terhadap isteri atau suami yang jelas menurutnya karena pemberatan hukuman ini juga ditujukan kepada suami atau isteri yang melakukan penganiayaan, maka setidaknya Pasal 356 mengandung prinsip keadilan gender. (Nursyahbani Katjasungkana,1994).

Kekerasan yang terjadi dalam rumah tangga tidak sejalan dengan pengertian dan tujuan dari terbentuknya sebuah rumah tangga (perkawinan) baik menurut hukum positif, adat dan agama. Pasal 1 Undang-Undang Nomor 1 tahun 1974 tentang Perkawinan menyatakan perkawinan adalah "ikatan lahir batin antara seorang pria dan seorang wanita sebagai suami istri dengan tujuan membentuk keluarga (rumah tangga) yang bahagia dan kekal berdasarkan Ketuhanan Yang Maha Esa." Suatu ikatan lahir adalah ikatan yang dapat dilihat atau disebut hubungan formil. Sebaliknya, ikatan batin adalah hubungan yang tidak formil atau suatu hubungan yang tidak dapat dilihat. Dalam kehidupan bersama ikatan batin tercermin dari adanya keturunan. Perkawinan ini seharusnya membuat suami dan istri merasa nyaman, diperhatikan, dibutuhkan, bebas dari

Copyright @ C 2016, LITIGASI, p-ISSN: 0853-7100; e-ISSN: 2442-2274 
Available online at: http://ejournal.unpas.ac.id/index.php/litigasi

Litigasi, Vol. 17(1), 2016, 3221-3255

DOI: http://dx.doi.org/10.23969/litigasi.v17i1.46

keterasingan dan kesepian sehingga kebutuhan terdalam sebagai manusia dapat terpenuhi. Dalam kenyataannya, tujuan perkawinan tersebut sering tidak tercapai karena di dalam perkawinan tersebut sering terjadi kekerasan dalam rumah tangga terutama kekerasan terhadap perempuan. Hal ini bertolak belakang dengan tujuan perkawinan yang ada di Pasal 1 Undang-Undang Nomor 1 tahun 1974 tentang Perkawinan yang menyatakan tujuan perkawinan adalah "membentuk keluarga (rumah tangga) yang bahagia dan kekal berdasarkan Ketuhanan Yang Maha Esa". Sejalan dengan tujuan perkawinan menurut Undang-Undang Nomor 1 tahun 1974 tentang Perkawinan, Soemijati menyatakan: “tujuan perkawinan adalah untuk memenuhi tuntutan hajat tabiat kemanusiaan, berhubungan antara laki-laki dan perempuan dalam rangka mewujudkan keluarga bahagia dengan dasar cinta dan kasih sayang, memperoleh keturunan yang sah dengan mengikuti ketentuanketentuan yang telah diatur oleh hukum" (Soemijati dalam bachtiar, 2004).

Terbentuknya Undang-Undang Nomor 23 tahun 2004 tentang Penghapusan Kekerasan dalam Rumah tangga yang disahkan pada tanggal 22 Sepetember 2004 tidak terlepas dari peran pemerintah di dalamnya karena undang-undang merupakan landasan hukum yang menjadi dasar dari seluruh kebijakan yang akan dibuat oleh pemerintah serta diharapkan dapat dijadikan sebagai perangkat hukum yang memadai, yang didalamnya antara lain mengatur mengenai pencegahan, perlindungan terhadap korban, dan penindakan terhadap pelaku kekerasan dalam rumah tangga, dengan tetap menjaga keutuhan demi keharmonisan keluarga. Akan tetapi pada kenyataannya secara umum kasus

Copyright $\odot$ 2016, LITIGASI, p-ISSN: 0853-7100; e-ISSN: 2442-2274 
Available online at: http://ejournal.unpas.ac.id/index.php/litigasi

Litigasi, Vol. 17(1), 2016, 3221-3255

DOI: http://dx.doi.org/10.23969/litigasi.v17i1.46

Kekerasan Dalam Rumah Tangga di Indonesia masih tinggi, bahkan cenderung mengalami peningkatan.

Berdasarkan dari Catatan Tahunan (CATAHU) KOMNAS Perempuan sepanjang tahun 2014 jumlah kasus kekerasan terhadap perempuan sebesar 293.220 sebagian besar dari data tersebut diperoleh dari kasus/perkara yang ditangani oleh 359 Pengadilan Agama di tingkat Kabupaten/Kota yang tersebar di 30 Provinsi di Indonesia, yaitu mencapai 280.710 kasus atau berkisar $96 \%$. Sisanya sejumlah 12.510 kasus atau berkisar $4 \%$ bersumber dari 191 lembaga lembaga mitra pengada layanan yang merespon dengan mengembalikan formulir pendataan yang dikirimkan oleh Komnas Perempuan (www.komnasperempuan.or.id).

Data di atas tidaklah menunjukkan jumlah kekerasan dalam rumah tangga yang sebenarnya, dipercaya masih banyak perkara kekerasan dalam rumah tangga yang tidak dilaporkan. Penyebab adanya non reporting crime (kejahatan tidak dilaporkan) adalah:

1) Si korban malu karena peristiwa ini telah mencemarkan dirinya baik secara fisik, psikologis, sosial;

2) Si korban berkewajiban melindungi nama baik keluarganya terutama pelaku adalah anggota keluarga;

3) Si korban merasa bahwa proses peradilan pidana belum tentu dapat membuat dipidananya pembuat;

4) Si korban khawatir bahwa diprosesnya kasus ini akan membawa cemar yang

Copyright @ C 2016, LITIGASI, p-ISSN: 0853-7100; e-ISSN: 2442-2274 
Available online at: http://ejournal.unpas.ac.id/index.php/litigasi

Litigasi, Vol. 17(1), 2016, 3221-3255

DOI: http://dx.doi.org/10.23969/litigasi.v17i1.46

lebih tinggi lagi bagi dirinya, misalnya publikasi di media massa;

5) Si korban khawatir ada pembalasan dari pelaku;

6) Lokasi kantor polisi yang jauh dari tempat tinggal korban membuatnya enggan melapor;

7) Keyakinan korban bahwa walaupun ia melapor ia tidak akan mendapatkan perlindungan khusus dari penegak hukum;

8) Ketidaktahuan korban bahwa yang dilakukan terhadapnya merupakan suatu bentuk tindak kekerasan" (Harkrisnowo dalam Luhulima, A.S, 2000).

Peningkatan jumlah kasus kekerasan terhadap perempuan dalam rumah tangga itu diantaranya dilatar belakangi oleh berbagai faktor diantaranya adalah faktor intern dan faktor extern. Hambatan yang datang dari korban (intern) dapat terjadi karena:

a) korban tidak mengetahui bahwa tindakan kekerasan yang dilakukan oleh suami merupakan perbuatan pidana atau perbuatan yang dapat dihukum. Oleh karena itu, korban tidak melaporkan tindak kekerasan yang dialaminya;

b) korban membiarkan tindakan kekerasan terhadap dirinya sampai berlarurlarut. Hal ini bisa disebabkan oleh korban berpendapat bahwa tindakan suami akan berubah;

c) korban berpendapat apa yang dialaminya adalah takdir atau nasibnya sebagai istri. Hal ini bisa disebabkan oleh korban berpendapat bahwa tindakan suami akan berubah;

Copyright @ C 2016, LITIGASI, p-ISSN: 0853-7100; e-ISSN: 2442-2274 
Available online at: http://ejournal.unpas.ac.id/index.php/litigasi

Litigasi, Vol. 17(1), 2016, 3221-3255

DOI: http://dx.doi.org/10.23969/litigasi.v17i1.46

d) korban mempunyai ketergantungan secara ekonomi pada pelaku tindak kekerasan;

e) korban mempertahankan status sosialnya, sehingga kalau sampai tindak kekerasan yang terjadi dalam rumah tangganya diketahui oleh orang lain, akan memperburuk status social keluarganya di dalam masyarakat;

f) korban takut akan ancaman dari suami;

g) korban khawatir keluarga akan menyalahkan dirinya karena dianggap tidak dapat menyelesaikan masalah rumah tangganya sendiri;

h) korban terlambat melaporkan tindakan kekerasan yang dialami, sehingga bukti-bukti fisik sudah hilang (Moerti Hadiati Soeroso, 2010:136-137).

Hambatan extern dapat terjadi karena:

1) Hambatan dapat dilakukan oleh keluarga korban karena kekerasan dalam rumah tangga adalah aib keluarga yang harus ditutupi agar tidak diketahui oleh masyarakat. Alasan yang lain adalah karena tindak kekerasan yang terjadi dalam rumah tangga merupakan urusan domestik atau urusan intern keluarga.

2) Hambatan yang lain datang dari masyarakat. Masih ada pendapat yang menganggap kekerasan dalam rumah tangga adalah urusan keluarga bukan merupakan kejahatan yang dapat diselesaikan melalui jalur hukum. Pendapat demikian masih masih mewarnai berbagai kalangan dalam masyarakat, sehingga akan merupakan hambatan bagi penegak hukum di bidang tindak kekerasan dalam rumah tangga,

Copyright @ C 2016, LITIGASI, p-ISSN: 0853-7100; e-ISSN: 2442-2274 
Available online at: http://ejournal.unpas.ac.id/index.php/litigasi

Litigasi, Vol. 17(1), 2016, 3221-3255

DOI: http://dx.doi.org/10.23969/litigasi.v17i1.46

3) Hambatan dari Negara:

a) Hambatan ini berupa ketentuan bahwa biaya visum et repertum harus dikeluarkan oleh korban. Bagi korban yang tidak mampu, hal ini merupakan hambatan dalam mencari keadilan.

b) Selain itu dimasukkannya kekerasan fisik, psikis dan seksual yang dilakukan oleh suami terhadap istri ke dalam delik aduan, sangat membatasi ruang gerak istri. Meskipun dalam undang-undang tidak disebutkan delik aduan absolute atau delik aduan relatif, tetap saja menempatkan istri pada posisi subordinatif. Hal ini tercantum dalam Pasal 51, 52 dan 53 UndangUndang Nomor 23 tahun 2004. Padahal pada awalnya sudah ditentukan bahwa kekerasan dalam rumah tangga merupakan suatu delik, suatu perbuatan yang dapat diproses secara hukum (Moerti Hadiati Soeroso, 2010:137-138).

Berdasarkan uraian di atas maka penulis merumuskan identifikasi masalah sebagai berikut: Apa Faktor penyebab terjadinya tindak kekerasan terhadap perempuan dalam rumah tangga? Bagaimana penegakan hukum perlindungan terhadap perempuan korban Kekerasan Dalam Rumah Tangga (KDRT)?

\section{PEMBAHASAN}

Kekerasan dalam rumah tangga merupakan fenomena sosial yang telah berlangsung dalam sebagian rumah tangga yang ada di Indonesia. Pasal 1 ayat (1) Undang-Undang Nomor 23 tahun 2004 tentang Penghapusan Kekerasan

Copyright @ 2016 , LITIGASI, p-ISSN: 0853-7100; e-ISSN: 2442-2274 
Available online at: http://ejournal.unpas.ac.id/index.php/litigasi

Litigasi, Vol. 17(1), 2016, 3221-3255

DOI: http://dx.doi.org/10.23969/litigasi.v17i1.46

dalam Rumah Tangga menyatakan, yang dimaksud dengan kekerasan dalam rumah tangga adalah:

Setiap perbuatan terhadap seseorang terutama perempuan, yang berakibat timbulnya kesengsaraan atau penderitaan secara fisik, seksual, psikologis, dan/atau penelantaran rumah tangga termasuk ancaman untuk melakukan perbuatan, pemaksaan, atau perampasan kemerdekaan secara melawan hukum dalam lingkup rumah tangga.

Menurut Sukri (2004:7) kekerasan dalam rumah tangga adalah: "setiap perbuatan yang dilakukan seseorang atau beberapa orang terhadap orang lain, yang berakibat atau mungkin berakibat kesengsaraan atau penderitaan fisik, seksual dan atau psikologi, termasuk ancaman perbuatan tertentu, pemaksaan atau perampasan kemerdekaan secara sewenang-wenang atau penekanan ekonomis yang terjadi dalam lingkup rumah tangga."

Pasal 2 ayat (1) menyebutkan yang termasuk dalam lingkup rumah tangga dalam undang-undang ini meliputi:

a. suami, isteri, dan anak;

b. orang-orang yang mempunyai hubungan keluarga dengan orang sebagaimana dimaksud pada huruf a karena hubungan darah, perkawinan, persusuan, pengasuhan, dan perwalian, yang menetap dalam rumah tangga; dan/atau

c. orang yang bekerja membantu rumah tangga dan menetap dalam rumah tangga tersebut.

Kaum perempuan dalam kenyataanya lebih rentan menjadi korban dari pada laki-laki di dalam kejahatan kekerasan dalam rumah tangga karena berbagai hal didalam masyarakat. "Tingginya pengorbanan kedudukan sosial, kesehatan dan ekonomi yang menjadi beban individu maupun masyarakat berkaitan erat

Copyright @ C 2016, LITIGASI, p-ISSN: 0853-7100; e-ISSN: 2442-2274 
Available online at: http://ejournal.unpas.ac.id/index.php/litigasi

Litigasi, Vol. 17(1), 2016, 3221-3255

DOI: http://dx.doi.org/10.23969/litigasi.v17i1.46

dengan kekerasan terhadap perempuan. Tindak kekerasan terhadap perempuan merupakan mekanisme-mekanisme sosial yang sangat besar peranannya dalam memaksa kaum perempuan untuk berada pada posisi yang lebih rendah daripada laki-laki. Dalam banyak kasus kekerasan terhadap perempuan dan anak-anak perempuan terjadi dalam keluarga atau di dalam rumah. Di tempat-tempat inilah kekerasan sering dibiarkan karena dianggap sebagai sesuatu yang biasa saja. Ketidakpedulian, penyalahgunaan fisik dan seksual, perkosaan terhadap anak-anak dan perempuan dewasa oleh anggota keluarga dan bukan anggota keluarga di dalam satu rumah tangga, maupun kejadian-kejadian di antara suami istri, sering berlalu tanpa dilaporkan. Oleh karena itu, kejadian seperti itu sukar ditemukan. Bahkan walaupun kejadian itu dilaporkan, sering gagal untuk melindungi korban dan gagal untuk menghukum para pelaku kekerasan tersebut (Moerti Hadiati Soeroso $2010: 109)$.

Selanjutnya, di Pasal 4 Undang-Undang Nomor 23 tahun 2004 yang mengatur tentang tujuan dari penghapusan kekerasan dalam rumah tangga tersebut yaitu:

1. Mencegah segala bentuk kekerasan dalam rumah tangga;

2. Melindugi korban kekerasan dalam rumah tangga;

3. Menindak pelaku kekerasan dalam rumah tangga; dan

4. Memelihara keutuhan rumah tangga yang harmonis dan sejahtera.

Copyright @ 9 2016, LITIGASI, p-ISSN: 0853-7100; e-ISSN: 2442-2274 
Available online at: http://ejournal.unpas.ac.id/index.php/litigasi

Litigasi, Vol. 17(1), 2016, 3221-3255

DOI: http://dx.doi.org/10.23969/litigasi.v17i1.46

Adapun bentuk-bentuk kekerasan dalam rumah tangga yang dilarang dalam Undang-Undang Nomor 23 tahun 2004 tentang Penghapusan Kekerasan dalam Rumah Tangga terdapat pada Pasal 5,6,7,8 dan 9. Bentuk-bentuk kekerasan yang dilarang yaitu:

a. Kekerasan fisik adalah perbuatan yang mengakibatkan rasa sakit, jatuh sakit atau luka berat.

b. Kekerasan psikis adalah perbuatan yang mengakibatkan ketakutan, hilangnya rasa percaya diri, hilangnya kemampuan untuk bertindak , rasa tidak berdaya, dan/atau penderitaan psikis berat pada seseorang.

c. Kekerasan seksual meliputi pemaksaan hubungan seksual yang dilakukan terhadap orang yang menetap dalam lingkup rumah tangga tersebut dan pemaksaan hubungan seksual terhadap salah seorang dalam lingkup rumah tangganya dengan orang lain untuk tujuan komersial dan/atau tujuan tertentu.

d. Penelantaran rumah tangga yaitu menelantarkan orang dalam lingkup rumah tangganya, padahal menurut hukum yang berlaku baginya atau karena persetujuan atau perjanjian ia wajib memberikan kehidupan, perawatan atau pemeliharaan kepada orang tersebut termasuk juga bagi setiap orang yang mengakibatkan ketergantungan ekonomi dengan cara membatasi dan/atau melarang untuk bekerja yang layak di dalam atau diluar rumah sehingga korban berada dibawah kendali orang tersebut.

Copyright @ C 2016, LITIGASI, p-ISSN: 0853-7100; e-ISSN: 2442-2274 
Available online at: http://ejournal.unpas.ac.id/index.php/litigasi

Litigasi, Vol. 17(1), 2016, 3221-3255

DOI: http://dx.doi.org/10.23969/litigasi.v17i1.46

Kekerasan dalam rumah tangga merupakan suatu tindakan yang dilakukan oleh orang yang berada didalam lingkup rumah rumah tangga sendiri sehingga mengakibatkan kesengsaraan, penderitaan fisik (seperti menendang, menampar, mengancam dengan suatu benda/senjata, bahkan menghilangkan nyawa/membunuh), psikis (seperti mengintimidasi, mencaci maki dan menghina), kekerasan seksual (seperti pemaksaan hubungan seksual baik dalam rumah tangga maupun pemaksaan seksual untuk komersial), serta penelantaran dalam rumah tangga (seperti, tidak memenuhi kebutuhan ekonomi dalam rumah tangga dan lain sebagainya).

A. Faktor Penyebab Terjadinya Kekerasan Terhadap Perempuan Korban Kekerasan Dalam Rumah Tangga

Banyak faktor yang menyebabkan terjadinya tindak kekerasan dalam rumah tangga. Faktor yang mempengaruhi bisa saja berasal faktor internal dan faktor ekternal. Faktor internal ini menyangkut diri pribadi. Hal ini biasanya timbul dikarenakan lingkungan keluarga/orang tua yang membentuk pribadi pelaku (suami) itu sendiri. Misalnya; Apabila tindak kekerasan mewarnai dalam kehidupan sebuah keluarga, kemungkinan besar anak-anak mereka nantinya akan mengalami hal yang sama setelah menikah nanti. Sedangkan faktor ekternal adalah berasal dari luar diri si pelaku kekerasan, misalnya: masalah keuangan, cemburu, faktor lingkungan sosial dan faktor pandangan masyarakat yang menganggap bahwa kedudukan laki-laki (suami) lebih tinggi daripada perempuan.

Copyright @ C 2016, LITIGASI, p-ISSN: 0853-7100; e-ISSN: 2442-2274 
Available online at: http://ejournal.unpas.ac.id/index.php/litigasi

Litigasi, Vol. 17(1), 2016, 3221-3255

DOI: http://dx.doi.org/10.23969/litigasi.v17i1.46

Fathul Djannah (2002) mengemukakan beberapa faktornya yaitu :

1) Kemandirian ekonomi istri. Secara umum ketergantungan istri terhadapsuami dapat menjadi penyebab terjadinya kekerasan, akan tetapi tidak sepenuhnya demikian karena kemandirian istri juga dapat menyebabkan istri menerima kekerasan oleh suami.

2) Karena pekerjaan istri. Istri bekerja di luar rumah dapat menyebabkan istri menjadi korban kekerasan.

3) Perselingkuhan suami. Perselingkuhan suami dengan perempuan lain atau suami kawin lagi dapat melakukan kekerasan terhadap istri.

4) Campur tangan pihak ketiga. Campur tangan anggota keluarga daripihak suami, terutama ibu mertua dapat menyebabkan suami melakukan kekerasan terhadap istri.

5) Pemahaman yang salah terhadap ajaran agama. Pemahaman ajaranagama yang salah dapat menyebabkan timbulnya kekerasan terhadap perempuan dalam rumah tangga.

6) Karena kebiasaan suami, dimana suami melakukan kekerasan terhadap istri secara berulang-ulang sehingga menjadi kebiaaan

B. Penegakan Hukum Perlindungan Terhadap Perempuan Korban Kekerasan Dalam Rumah Tangga (KDRT)

Penegakan hukum adalah suatu proses atau upaya yang dilakukan untuk mewujudkan keadilan serta tegaknya norma-norma hukum secara nyata sebagai

Copyright @ 2016 , LITIGASI, p-ISSN: 0853-7100; e-ISSN: 2442-2274 
Available online at: http://ejournal.unpas.ac.id/index.php/litigasi

Litigasi, Vol. 17(1), 2016, 3221-3255

DOI: http://dx.doi.org/10.23969/litigasi.v17i1.46

pedoman perilaku dalam kehidupan bermasyarakat dan bernegara. Penegakan hukum merupakan usaha untuk mewujudkan ide-ide dan konsep hukum yang diharapkan rakyat menjadi kenyataan.

"Penegakan hukum merupakan suatu proses yang melibatkan banyak hal" (Dellyana, Shant.1988:32). Secara konseptual, maka inti dan arti penegakan hukum terletak pada kegiatan menyerasikan hubungan nilai-nilai yang terjabarkan di dalam kaidah-kaidah yang mantap dan mengejewantahkan dari sikap tindak sebagai rangkaian penjabaran nilai tahap akhir, untuk menciptakan, memelihara dan mempertahankan kedamaian pergaulan hidup (Soerjono Soekanto, 1983:2).

Penanganan terhadap perempuan korban kekerasan dalam rumah tangga selain penegakan hukum, perempuan yang mendapat perlakuan kekerasan dalam rumah tangga sewajarnya harus mendapat perlindungan. Perlindungan terhadap perempuan sebagai korban kekerasan merupakan tanggung jawab bersama antara, individu, masyarakat, aparat penegakkan serta lembaga sosial. Hal ini sejalan dengan yang terdapat pada Pasal 1 ayat (4) Undang-Undang Nomor. 23 tahun 2004 tentang Penghapusan Kekerasan Dalam Rumah Tanga menyatakan, perlindungan adalah " segala upaya yang ditujukan untuk memberikan rasa aman kepada korban yang dilakukan oleh pihak keluarga, advokat, lembaga sosial, kepolisian, kejaksaan, pengadilan, atau pihak lainnya baik sementara maupun berdasarkan penetapan pengadilan". Selain itu Perlindungan terhadap perempuan juga sesuai dengan Pasal 27 ayat (1) UUD 1945, menentukan bahwa setiap

Copyright @ 2016, LITIGASI, p-ISSN: 0853-7100; e-ISSN: 2442-2274 
Available online at: http://ejournal.unpas.ac.id/index.php/litigasi

Litigasi, Vol. 17(1), 2016, 3221-3255

DOI: http://dx.doi.org/10.23969/litigasi.v17i1.46

warga negara bersamaan kedudukannya di dalam hukum dan pemerintahan dan wajib menjunjung hukum dan pemerintahan wajib menjunjung hukum dan pemerintahan itu dengan tidak ada kecualinya (hal ini menunjukkan bahwa setiap warga negara sama kedudukannya dimata hukum dan pemerintahan).

Sementara itu Barda Nawawi (2010:61) mengemukakan:

Dapat diartikan sebagai perlindungan untuk memperoleh jaminan/santunan hukum atas penderitaan/kerugian orang yang telah menjadi korban tindak pidana (jadi identik dengan penyantunan korban). Bentuk santunan ini dapat berupa pemulihan nama baik (rehabilitasi), pemulihan keseimbangan batin (antara lain, dengan pemaafan), pemulihan keseimbanan batin (antara lain, denga pemaafan), pemberian ganti rugi (restitusi,kompensasi, jaminan/santunan kesejahteraan sosial).

Pasal 10 Undang-Undang Penghapusan Kekerasan Dalam Rumah Tangga menentukan korban berhak mendapat perlindungan dari pihak keluarga, kepolisian, pengadilan, advokat. Selain itu Pemerintah dalam hal ini juga perlu bertanggung jawab terhadap seperti yang tertuang dalam Pasal 11 UndangUndang Nomor 23 tahun 2004 yang berbunyi: “Pemerintah bertanggung jawab dalam upaya pencegahan kekerasan dalam rumah tangga".

Guna tegak atau berjalannya perlindungan hukum terhadap perempuan korban kekerasan dalam rumah tangga diperlukan penegakan hukum yang jelas. Dalam penegakan hukum tersebut ada beberapa faktor yang mempengaruhinya.

Menurut Soerjono Soekanto (2004:42) dalam penegakan hukum akan dipengaruhi dari beberapa faktor :

a. Faktor Hukumnya Sendiri

Copyright @ C 2016, LITIGASI, p-ISSN: 0853-7100; e-ISSN: 2442-2274 
Available online at: http://ejournal.unpas.ac.id/index.php/litigasi

Litigasi, Vol. 17(1), 2016, 3221-3255

DOI: http://dx.doi.org/10.23969/litigasi.v17i1.46

Dalam praktik penyelenggaraan hukum di lapangan ada kalanya terjadi pertentangan antara kepastian hukum dan keadilan, hal ini disebabkan oleh konsepsi keadilan merupakan suatu rumusan yang bersifat abstrak, sedangkan kepastian hukum merupakan suatu prosedur yang telah ditentukan secara normatif. Justru itu, suatu kebijakan atau tindakan yang tidak sepenuhnya berdasar hukum merupakan sesuatu yang dapat dibenarkan sepanjang kebijakan atau tindakan itu tidak bertentangan dengan hukum. Maka pada hakikatnya penyelenggaraan hukum bukan hanya mencakup low enforcement saja, namun juga peace maintenance, karena penyelenggaraan hukum sesungguhnya merupakan proses penyerasian antara nilai kaedah dan pola perilaku nyata yang bertujuan untuk mencapai kedamaian.

Guna mengetahui bekerjanya suatu hukum dapat dianalisis dari 3 komponen sebagai berikut: substansi hukum, struktur hukum dan budaya hukum (Lawrence Friedman dalam A. Reni Widyaastuti:264).

Pertama, berkaitan dengan subtansi hukum, disamping terdapat instrumen hukum yang bertujuan dalam memberikan keadilan terhadap perempuan korban Kekerasan Dalam Rumah Tangga namun disisi lain terdapat masalah rumah tangga, perundang-undangan dan kebijakan lain yang memberi dampak merugikan bagi perempuan, Bahkan seringkali interpretasi dari ajaran agama dan adat yang meneguhkan subordinasi perempuan diakomodasi dengan substansi peraturan perundang-undangan. Para penganut Feminist legal

Copyright @ 2016 , LITIGASI, p-ISSN: 0853-7100; e-ISSN: 2442-2274 
Available online at: http://ejournal.unpas.ac.id/index.php/litigasi

Litigasi, Vol. 17(1), 2016, 3221-3255

DOI: http://dx.doi.org/10.23969/litigasi.v17i1.46

theory mengatakan bahwa prinsip dasar dari sistem hukum bersifat patriarkhis. Dalam arti hukum-hukum tersebut dibuat dan disusun dalam kerangka kaca mata laki-laki, untuk kepentingan laki-laki maka mengabaikan pengalaman perempuan bahkan menempatkan perempuan pada relasi kekuasaan yang timpang baik dalam keluarga maupun dalam masyarakat. Kedua, dalam penegakan hukum dilapangan, struktur hukum, para penegak hukum sering tidak berpihak kepada korban perempuan, bukan karena ketidakpahaman dan ketiadaan perspektif perempuan dikalangan penegak hukum, tetapi juga struktur dan prosedur yang ketat menghalangi para penegak hukum untuk membuat terobosan dan interpretasi baru meskipun demi persoalan kemanusiaan. Memang benar kelangsungan sebuah struktur mensyaratkan adanya ketaatan pada aturan dan prosedur, namun sebenarnya persoalan dapat dicari dalam paradigma atau cara pandang para penegak hukum dalam memandang hukum. Pemikiran yang logistis yang dianut sarjana hukum pada umumnya terutama yang berkecimpung dalam hukum pidana menyebabkan sukarnya mereka memberi interpretasi lain atau melakukan terobosanterobosan yang dibutuhkan. Ketiga, masih kuatnya budaya hukum masyarakat, yaitu kekuatan-kekuatan sosial berupa ide, gagasan, nilai-nilai, norma kebiasaan dan sebagainya yang potensial menempatkan perempuan dalam posisi submissive baik dalam keluarga maupun masyarakat. Dari keseluruhan sistem hukum ini, budaya hukum merupakan faktor yang sangat berpengaruh terhadap dapat tidaknya suatu substansi hukum bekerja dalam masyarakat.

Copyright @ 2016 , LITIGASI, p-ISSN: 0853-7100; e-ISSN: 2442-2274 
Available online at: http://ejournal.unpas.ac.id/index.php/litigasi

Litigasi, Vol. 17(1), 2016, 3221-3255

DOI: http://dx.doi.org/10.23969/litigasi.v17i1.46

Undang-Undang Tentang Penghapusan Kekerasan dalam Rumah Tangga dapat diterapkan dalam kasus Kekerasan dalam Rumah Tangga atau tidak tergantung pada seberapa kuatnya budaya hukum yang hidup di masyarakat (A. Reni Widyaastuti, 2007:264-265).

Pengesahan Undang-Undang Nomor 23 tahun 2004 tentang Penghapusan Kekerasan dalam Rumah Tangga (PKDRT) merupakan tonggak bersejarah dalam penanganan perkara Kekerasan dalam Rumah Tangga (KDRT). Beberapa kelebihan Undang-Undang PKDRT dibandingkan KUHP adalah:

1. Undang-Undang PKDRT telah membawa kasus KDRT dari wilayah privat suami-istri ke ranah publik;

2. Saksi korban yang selama ini terabaikan bisa dijadikan dasar hukum dengan ditambah satu alat bukti lain;

3. Lingkup rumah tangga tidak hanya meliputi suami-istri, tetapi lebih diperluas lagi sesuai isi Pasal 2 Undang-Undang PKDRT;

4. Lingkup KDRT tidak hanya kekerasan fisik, tetapi juga mencakup kekerasan psikis, penelantaran rumah tangga, dan seksual (Jamaa, dan Hadidjah 2008:37-39).

Selain kelebihan terdapat juga bebrapa kelemahan dalam UndangUndang PKDRT seperti Undang-Undang PKDRT tidak mempunyai hukum acara sendiri sehingga penegak hukum berpedoman pada KUHAP yang kaku dan tidak ramah terhadap korban KDRT, ancaman pidana Undang-Undang

Copyright $\odot$ 2016, LITIGASI, p-ISSN: 0853-7100; e-ISSN: 2442-2274 
Available online at: http://ejournal.unpas.ac.id/index.php/litigasi

Litigasi, Vol. 17(1), 2016, 3221-3255

DOI: http://dx.doi.org/10.23969/litigasi.v17i1.46

PKDRT berbentuk alternative (penjara atau denda) bukan berbentuk kumulatif (penjara atau denda). Begitu juga pada Pasal 44 ayat (4), Pasal 45 ayat (2), dan Pasal 46, tidak dijelaskan apakah pasal tersebut merupakan delik aduan absolute atau delik aduan relatif. Karena ketidak jelasan pengaturan ini perempuan korban kekerasan dalam rumah tangga tetap dalam posisi yang lemah di mata hukum. Ada suatu kebimbangan lain bagi perempuan korban kekerasan dalam rumah tangga apabila seorang suami melakukan tindak kekerasan dilaporkan kepada aparat penegak hukum maka tidak jarang malah akan terjadi perceraian sementara kebanyakan korban kekerasan dalam rumah tangga ini memiliki ketegantungan ekonomi terhadap suaminya.

b. Faktor penegak hukum

Fungsi hukum, mentalitas atau kepribadian petugas penegak hukum memainkan peranan penting, kalau peraturan sudah baik, tetapi kualitas petugas kurang baik, ada masalah. Oleh karena itu, salah satu kunci keberhasilan dalam penegakan hukum adalah mentalitas atau kepribadian penegak hukum.

Penegak hukum (polisi, jaksa, hakim) masih banyak yang bersikap bias gender, bahkan acapkali menggunakan pendekatan victim blaming dan victim participating dalam merespon kasus kekerasan. Dalam penanganan kasus kekerasan dalam rumah tangga, Nurherwati melihat proses penyelesaiannya hanya mengutamakan aspek hukum dan meminggirkan keadilan bagi korban. Misalnya, dalam menangani sebuah perkara, aparat penegak hukum hanya

Copyright $\odot$ 2016, LITIGASI, p-ISSN: 0853-7100; e-ISSN: 2442-2274 
Available online at: http://ejournal.unpas.ac.id/index.php/litigasi

Litigasi, Vol. 17(1), 2016, 3221-3255

DOI: http://dx.doi.org/10.23969/litigasi.v17i1.46

melihat unsur pidana, jika terpenuhi maka langsung diproses. Parahnya, tak jarang ditemukan aparat penegak hukum tidak dapat membedakan mana korban dan pelaku. "Ujungnya, 10 persen korban malah dipidanakan (www.hukumonline.com). Selain dari aparat penegak hukum korban kekerasan memiliki keraguan, kekhawatiran, dan ketakutan untuk melaporkan kejadian yang dialami. Korban merasa takut pada proses hukum yang akan dijalani. Kesadaran dan kepekaan gender para penegak hukum masih kurang, sehingga kadang-kadang korban justru menjadi objek.

Menurut Jimmly Asshidiqie, Ada tiga elemen penting yang mempengaruhi mekanisme bekerjanya aparat dan aparatur penegak hukum, elemen tersebut antara lain : (1) istitusi penegak hukum beserta berbagai perangkat sarana dan prasarana pendukung dan mekanisme kerja kelembagaannya; (2) budaya kerja yang terkait dengan aparatnya, termasuk mengenai kesejahteraan aparatnya; dan (3) perangkat peraturan yang mendukung baik kinerja kelembagaanya maupun yang mengatur materi hukum yang dijadikan standar kerja, baik hukum materilnya maupun hukum acaranya. Upaya penegakan hukum secara sistematik haruslah memperhatikan ketiga aspek itu secara simultan, sehingga proses penegakan hukum dan keadilan secara internal dapat diwujudkan secara nyata.

Peran penegak hukum dalam hal ini kepolisian dalam sistem perlindungan terhadap perempuan korban kekerasan dalam rumah tangga Undang-Undang Nomor 23 tahun 2004 tentang Penghapusan Kekerasan

Copyright @ C 2016, LITIGASI, p-ISSN: 0853-7100; e-ISSN: 2442-2274 
Available online at: http://ejournal.unpas.ac.id/index.php/litigasi

Litigasi, Vol. 17(1), 2016, 3221-3255

DOI: http://dx.doi.org/10.23969/litigasi.v17i1.46

Dalam Tangga terdapat pada Pasal 16 sampai dengan Pasal 20 yang mengatur sebagai berikut.

(1) Dalam waktu 1 x 24 (satu kali dua puluh empat) jam terhitung sejak mengetahui atau menerima laporan kekerasan dalam rumah tangga, kepolisiam wajib segera memberikan perlindungan sementara pada korban yang diberikan paling lama 7 (tujuh) hari sejak korban diterima atau ditangani.

(2) Dalam waktu 1 x 24 (satu kali dua puluh empat) jam terhitung sejak pemberian perlindungan sementara terhadap korban, kepolisian wajib meminta surat penetapan perintah perlindungan dari pengadilan.

(3) Dalam memberikan perlindungan sementara, kepolisian dapat bekerjasama dengan tenaga kesehatan, pekerja sosial, relawan pendamping dan/atau pembimbing rohani untuk mendampingi korban.

(4) Kepolisian wajib memberikan keterangan kepada korban tentang hak korban untuk mendapat pelayanan dan pendampingan.

(5) Kepolisian wajib segera melakukan penyelidikan setelah mengetahui atau menerima laporan tentang terjadinya Kekerasan Dalam Rumah Tangga.

(6) Kepolisian segera menyampaikan kepada korban tentang:

a) Identitas petugas untuk pengenalan kepada korban, 
Available online at: http://ejournal.unpas.ac.id/index.php/litigasi

Litigasi, Vol. 17(1), 2016, 3221-3255

DOI: http://dx.doi.org/10.23969/litigasi.v17i1.46

b) Kekerasan dalam rumah tangga adalah kejahatan terhadap martabat kemanusian

c) Kewajiban kepolisian untuk melindungi korban.

Peran Advokat dalam memberikan perlindungan dan pelayanan bagi korban kekerasan dalam rumah tangga terdapat pada Pasal 25 UndangUndang Nomor 23 tahun 2004 tentang Penghapusan Kekerasan dalam Rumah Tangga yang menyatakan:

Dalam hal memberikan perlindungan dan pelayanan, advokat wajib:

a. memberikan konsultasi hukum yang mencakup informasi mengenai hakhak korban dan proses peradilan;

b. mendampingi korban di tingkat penyidikan, penuntutan dan pemeriksaan dalam sidang pengadilan dan membantu korban untuk secara lengkap memaparkan kekerasan dalam rumah tangga yang dialaminya; atau

c. melakukan koordinasi dengan sesama penegak hukum, relawan pendamping, dan pekerja sosial agar prose peradilan berjalan sebagaimana mestinya.

Undang-undang juga mengatur tentang peran pengadilan dalam memberikan perlindungan terhadap korban kekerasan dalam rumah tangga, khususnya mengenai pelaksanaan mekanisme perintah perlindungan. Kepolisian harus meminta surat penetapan perintah perlindungan dari pengadilan. Setelah menerima permohonan itu, pengadilan harus:

a. mengeluarkan surat penetapan yang berisi perintah perlindungan bagi korban dan anggota keluarga lain;

Copyright @ C 2016, LITIGASI, p-ISSN: 0853-7100; e-ISSN: 2442-2274 
Available online at: http://ejournal.unpas.ac.id/index.php/litigasi

Litigasi, Vol. 17(1), 2016, 3221-3255

DOI: http://dx.doi.org/10.23969/litigasi.v17i1.46

b. atas permohonan korban atau kuasanya, pengadilan dapat mempertimbangkan untuk menetapkan suatu kondisi khusus yakni pembatasan gerak pelaku, larangan memasuki tempat tinggal bersama, larangan membuntuti, mengawasi atau mengintimidasi korban.

Dalam penegakan hukum terhadap Undang-Undang Pengahapusan Kekerasan Dalam Rumah Tangga terdapat sejumlah kendala: Pertama, delik Kekerasan Dalam Rumah Tangga yang dirumuskan dalam Undang-Undang Penghapusan Kekerasan Dalam Rumah Tangga "setengah hati" sehingga dalam pelaksanaan hampir semua bentuk Kekerasan Dalam Rumah Tangga dianggap delik aduan dan "mentok" sebagai kekerasan yang tidak menimbulkan akibat (secara fisik); Kedua, bias persepsi penegak hukum sejak tahap awal terhadap Kekerasan Dalam Rumah Tangga sehingga Kekerasan Dalam Rumah Tangga seringkali dianggap sebagai persoalan privat dan kurang mendapat prioritas; Ketiga, penegak hukum cenderung melihat Kekerasan Dalam Rumah Tangga adalah kekerasan fisik sehingga pembuktian terhadap dampak kekerasan hanya dilihat kasat mata saja padahal Kekerasan Dalam Rumah Tangga selalu menimbulkan dampak ganda, keempat, perlindungan hukum yang dirumuskan dalam Undang-Undang Penghapusan Kekerasan Dalam Rumah Tangga dalam pelaksanaannya terhambat karena secara teknis belum ada persamaan persepsi penegak hukum, kelima, paradigma hukum pidana yang bergerak hanya antara perbuatan dan orang dan belum menyentuh korban mengakibatkan 
Available online at: http://ejournal.unpas.ac.id/index.php/litigasi

Litigasi, Vol. 17(1), 2016, 3221-3255

DOI: http://dx.doi.org/10.23969/litigasi.v17i1.46

kedudukan korban dalam sistem peradilan pidana masih belum diperhatikan (Hamida A, 2010:477).

c. Faktor sarana dan fasilitas

Faktor sarana atau fasilitas pendukung mencakup perangkat lunak dan perangkat keras, salah satu contoh perangkat lunak adalah pendidikan. Pendidikan yang diterima oleh Polisi dewasa ini cenderung pada hal-hal yang praktis konvensional, sehingga dalam banyak hal polisi mengalami hambatan di dalam tujuannya, diantaranya adalah pengetahuan tentang kejahatan computer, dalam tindak pidana khusus yang selama ini masih diberikan wewenang kepada jaksa, hal tersebut karena secara teknis yuridis polisi dianggap belum mampu dan belum siap. Walaupun disadari pula bahwa tugas yang harus diemban oleh polisi begitu luas dan banyak.

Yang dimaksudkan Sarana atau fasilitas tersebut, antara lain, mencakup tenaga manusia yang bependidikan dan terampil, organisasi yang baik, peralatan yang memadai, keuangan yang cukup, dan seterusnya (Leden Marpaung dalam Anastasia Sitompul, 2015). Jika fasilitas pendukung tidak terpenuhi maka mustahil penegakan hukum akan nencapai tujuannya. Kepastian dan kecepatan penyelesaian perkara tergantung pada fasilitas pendukung yang ada dalam bidang-bidang pencegahan dan pemberantasan kejahatan. Menurut Soerjono Soekanto, menyatakan "bahwa tidak mungkin penegakan hukum akan berlangsung dengan lancar tanpa adanya sarana atau fasilitas yang memadai."

Copyright @ 2016 , LITIGASI, p-ISSN: 0853-7100; e-ISSN: 2442-2274 
Available online at: http://ejournal.unpas.ac.id/index.php/litigasi

Litigasi, Vol. 17(1), 2016, 3221-3255

DOI: http://dx.doi.org/10.23969/litigasi.v17i1.46

Berkaitan dengan penanganan untuk kasus kekerasan dalam rumah tangga, beberapa fasilitas khusus telah disediakan, antara lain Unit Perlindungan Perempuan dan Anak, Pusat Pelayanan Terpadu (PPT) yang memberikan pelayanan gratis bagi korban kekerasan dalam rumah tangga dalm hal hukum, medis, psikologis dan perlindungan sosial.

d. Faktor masyarakat

Penegakan hukum berasal dari masyarakat dan bertujuan untuk mencapai kedamaian di dalam masyarakat. Setiap warga masyarakat atau kelompok sedikit banyaknya mempunyai kesadaran hukum, persoalan yang timbul adalah taraf kepatuhan hukum, yaitu kepatuhan hukum yang tinggi, sedang, atau kurang. Adanya derajat kepatuhan hukum masyarakat terhadap hukum, merupakan salah satu indikator berfungsinya hukum yang bersangkutan.

Kesadaran hukum umumnya dipahami sebagai kerelaan warga negara untuk tunduk pada hukum dalam arti mematuhi larangan dan menjalankan perintah yang tercantum dalam aturan hukum dan kesadaran atas nilai-nilai yang terdapat di dalam diri manusia, tentang hukum yang ada atau tentang hukum yang diharapkan ada (Husain Kasim dkk,dalam Ni'mah, 2012).

Ada banyak faktor sosial, yang melestarikan adanya kekerasan dalam rumah tangga dan menyulitkan korban memeperoleh dukungan dan pendampingan dari masyarakat, yakni:

Pertama, dan yang utama adalah ketimpangan relasi antara laki-laki dan perempuan; baik di rumah tangga, maupun dalam keidupan publik. Di

Copyright @ C 2016, LITIGASI, p-ISSN: 0853-7100; e-ISSN: 2442-2274 
Available online at: http://ejournal.unpas.ac.id/index.php/litigasi

Litigasi, Vol. 17(1), 2016, 3221-3255

DOI: http://dx.doi.org/10.23969/litigasi.v17i1.46

keluarga misalnya, kebanyakan masyarakat percaya bahwa suami adalah pemimpin bahkan penguasa keluarga. Istri diposisikan seperti milik penuh suami, yang berada pada kontrol dan pengawasannya. Pengontrolan ini tidak sedikit, yang pada akhirnya menggunakantindak kekerasan.

Kedua, ketergantungan istri terhadap suami secara penuh. Terutama untuk masalah ekonomi, yang membuat istri benar-benar berada dibawah kekuasaan suami. Posisi rentan ini sering menjadi pelampiasan bagi suami, ketika dia menghadapi persoalan-persoalan yang sebenarnya berada diluar rumah tangga.

Ketiga, sikap kebanyakan masyarakat terhadap kekerasan dalam rumah tangga yang cenderung abai.

Keempat, keyakinan-keyakinan yang berkembang di masyarakat termasuk yang mungkin bersumber dari tafsir agama. Bahwa perempuan harus mengalah, bersabar atas segala persoalan keluarga, harus pandai menjaga rahasia keluarga, keyakinan tentang pentingnya keluarga ideal yang penuh dan lengkap, tentang istri shalihah, juga kekhawatiran-kekhawatiran terhadap proses perceraian dan akibat dari perceraian.

Kelima, mitos tentang kekerasan dalam rumah tangga yang muncul didalam masyarakat yang pada akhirnya memojokkan korban dan menjauhkan korban untuk mendapatkan bantuan secara (Faqihuddin AK dan Ummu AM dalam Guse Prayudi, 2011:2-3).

Copyright @ 2016, LITIGASI, p-ISSN: 0853-7100; e-ISSN: 2442-2274 
Available online at: http://ejournal.unpas.ac.id/index.php/litigasi

Litigasi, Vol. 17(1), 2016, 3221-3255

DOI: http://dx.doi.org/10.23969/litigasi.v17i1.46

e. Faktor kebudayaan

Berdasarkan konsep kebudayaan sehari-hari, orang begitu sering membicarakan soal kebudayaan. Kebudayaan menurut Soerjono Soekanto, mempunyai fungsi yang sangat besar bagi manusia dan masyarakat, yaitu mengatur agar manusia dapat mengerti bagaimana seharusnya bertindak, berbuat, dan menentukan sikapnya kalau mereka berhubungan dengan orang lain. Dengan demikian, kebudayaan adalah suatu garis pokok tentang perikelakuan yang menetapkan peraturan mengenai apa yang harus dilakukan, dan apa yang dilarang.

Kebudayaan (sistem) hukum pada dasarnya mencangkup nilai-nilai yang mendasari hukum yang berlaku, nilai-nilai yang merupakan konsepsi-konsepsi abstrak mengenai apa yang dianggap baik (hingga dianuti) dan apa yang diangap buruk (sehingga dihindari). Nilai-nilai tersebut merupakan pasangan nilai-nilai yang mencerminkan dua keadaan ekstrim yang harus diserasikan. Pasangan nilai yang berperan dalam hukum menurut Soerdjono Soekanto (2008) adalah sebagai berikut:

1. Nilai ketertiban dan ketenteraman.

2. Nilai jasmaniah/kebendaan dan nilai rohaniah/keakhlakan.

3. Nilai kelanggengan/konservatisme dan kebaruan/inovatisme.

Dengan adanya nilai-nilai tersebut diharapkan ada keserasian atau hubungan timbal balik antara hukum adat dan hukum positif di Indonesia.

Copyright @ C 2016, LITIGASI, p-ISSN: 0853-7100; e-ISSN: 2442-2274 
Available online at: http://ejournal.unpas.ac.id/index.php/litigasi

Litigasi, Vol. 17(1), 2016, 3221-3255

DOI: http://dx.doi.org/10.23969/litigasi.v17i1.46

Kemudian diharapkan juga ada keserasian antara kedua nilai tersebut akan menempatkan hukum pada tempatnya.

Pada persoalan kekerasan dalam rumah tangga di Indonesia ada banyak faktor yang menjadi penyebabnya, salah satunya adalah budaya patriarkhi. Pengertian dari patriarkhi adalah sebuah sistem sosial dimana laki-laki memiliki kontro dan kekuasaan yang lebih tinggi dengan perempuan berada di bawahnya/subordinat (S.Walby dalam Fatahillah A.Syukur, 2011:25).

\section{SIMPULAN DAN SARAN}

\section{A. Simpulan}

1. Banyak faktor penyebab terjadinya tindak kekerasan terhadap perempuan dalam rumah tangga antara lain adalah faktor internal atau faktor yang terjadi dari diri sipelaku (suami) itu sendiri. Kepribadian ini terbentuk melalui interaksi dalam keluarga dimasa kanak-kanak. Apabila tindak kekerasan mewarnai kehidupan orang tua kemungkinan besar disaat anakanak tersebut menikah akan mengalami hal yang sama nantinya. Faktor lain penyebab terjadinya adalah faktor ekternal dimana faktor yang mempengaruhi adalah diluar diri si pelaku seperti: faktor ekonomi, faktor sosial serta faktor pandangan masyarakat yang masih menganggap bahwa kedudukan laki-laki lebih tinggi dari kedudukan perempuan.

2. Dalam penegakan perlindungan terhadap perempuan banyak hal yang mempengaruhinya, antara lain faktor hukum itu sendiri, faktor 
Available online at: http://ejournal.unpas.ac.id/index.php/litigasi

Litigasi, Vol. 17(1), 2016, 3221-3255

DOI: http://dx.doi.org/10.23969/litigasi.v17i1.46

penegakan hukum, faktor sarana dan fasilitas, faktor masyarakat dan faktor budaya.

B. Saran

1. Untuk mengatasi/mengurangi terjadinya tindakan kekerasan dalan rumah tangga (KDRT) terhadap perempuan diharapkan peran dari berbagai pihak, antara lain peran dari pemerintah untuk mensosialisasikan pada masyarakat bahwa tindakan KDRT merupakan tindakan tidak dibenarkan dan dapat diberikan sanksi hukuman serta peran dari media massa dan media cetak juga berpengaruh besar untuk dapat mencegah/mengurangi tindak KDRT tersebut dengan memberikan suatu pemberitaan yang bisa merubah pola budaya yang selama ini ada ditengah masyarakat.

2. Dalam memberikan perlindungan terhadap perempuan korban kekerasan dalam rumah tangga diharapkan bukan hanya tugas para aparat penegak hukum, tapi diperlukan juga peran dari berbagai pihak seperti tokoh masyarakat, keluarga korban, lembaga sosial dan lain sebagainya sehingga dapat segera menyelamatkan/mengurangi korban kekerasan dalam rumah tangga yang sampai saat ini masih banyak terjadi.

Copyright @ $\odot$ 2016, LITIGASI, p-ISSN: 0853-7100; e-ISSN: 2442-2274 


\section{DAFTAR PUSTAKA}

\section{BUKU}

A. Nunuk P .Murniati, 2004, Getar Gender 1, Perempuan Indonesia dalam Perspektif Sosial, Politik, Ekonomi, Hukum dan HAM, Magelang: Indonesia Tara.

Andre Vesa dalam Aroma Elmina Martha, 2013, Proses Pembentukan Hukum Kekerasan Terhadap Perempuan di Indonesia dan Malaysia, Yogyakarta: Aswaja Pressindo.

Barda Nawawi, 2010, Masalah Penegakan Hukum dan Kebijakan Hukum Pidana dalam Penanggulangan Kejahatan, Penerbit Prenada Media Group.

Dellyana. Shant, 1988, Konsep Penegakan Hukum,Yogyakarta: Liberty.

Fathul Djannah, 2002, Kekerasan Terhadap Istri, Yogyakarta: LKIS.

Fatahillah A. Syukur, 2011, Mediasi Perkara KDRT (Kekerasan Dalam Rumah Tangga) Teori dan Praktek di Pengadilan Indonesia, Bandung: Mandar Maju.

Guse Prayudi, 2011, Berbagai Aspek Tindak Pidana Kekerasan Dalam Rumah Tangga, Yogyakarta: Merkid Press.

Jamaa dan Hadidjah, 2008, Hukum Islam dan Undang-Undang Anti Kekerasan Dalam Rumah Tangga, Surabaya: PT. Bina IImu.

Jack Donely, 2008, Universal Human Right in Theory and Practice dalam Hukum Hak Asasi Manusia, (Ed. Knut D. Asplund, Suparman marzuki, Eko Riyadi), Yogyakarta: PUSHAM UII.

Luhulima. A.S., 2000, Pemahaman Bentuk-Bentuk Kekerasan terhadap Perempuan dan Alternatif Pemecahannya, Jakarta: PT. Alumni.

Moerti Hadiati Soeroso, 2010, Kekerasan Dalam Rumah Tangga Dalam Perspektif Yuridis-Viktimologis, Jakarta: Sinar Grafika.

Moerti Hadiati Soeroso, 2010, Kekerasan dalam Rumah Tangga dalam perspektif Yuridis - Viktimologis, Jakarta: Sinar Grafika.

Munir Fuady, 2009, Teori Negara Hukum Modern (Rehctstaat), Bandung: Refika Aditama.

Copyright $\odot$ 2016, LITIGASI, p-ISSN: 0853-7100; e-ISSN: 2442-2274 
Majelis Permusyawaratan Rakyat Republik Indonesia, 2010, Panduan Pemasyarakatan Undang-Undang Dasar Republik Indonesia Tahun 1945.

Nursyahbani Katjasungkana, Seminar Aspek Hukum Kekerasan Terhadap Perempuan, Jakarta: 15-16 Desember 1994, BPHN.

Rika Saraswati, 2006, Perempuan dan Penyelesaian Kekerasan Dalam Rumah Tangga, Bandung: Citra Aditya Bakti.

Soerjono Soekanto, 2004, Faktor-Faktor Yang Mempengaruhi Penegakan Hukum Cetakan Kelima, Jakarta: Raja Grafindo Persada.

Schuler. Margaret. A \& Thomas. Doroty Q. (penyunting), 2001, Hak Asasi Manusia Kaum Perempuan Langkah Demi Langkah, Jakarta: Pusaka Sinar Harapan.

Sukri. S., 2004, Islam Menentang Kekerasan Terhadap Istri, Yogyakarta: Gama Media.

\section{JURNAL}

A. Reni Widyaastuti, 2007, Hukum dan Kekerasan dalam Rumah Tangga, Jurnal Ilmu Hukum Pro Justitia, Vol. 25 No. 3.

Anastasia Hana Sitompul, 2015, Kajian Hukum Tentang Tindak Kekerasan Seksual Terhadap Anak di Indonesia, Jurnal Lex Crimen, Vol. IV. No.1.

Hamida, 2010, Perlindungan Hukum Terhadap Koerban Kekerasan Dalam Rumah Tangga dalam Putusan Pengadilan Negeri Sebagai Implementasi Hak-hak Korban, Jurnal Ilmu Hukum, Vol. 17. No. 3.

Ni'mah, 2012, Efektifitas Penegakan Hukum Penghapusan Kekerasan dalam Rumah Tangga, Jurnal Mimbar Hukum, Vol. 24 No. 1.

Ratna Batara Munti dalam Novianty Djafri, Jurnal INOVASI, Volume 5. Nomor 4. Desember 2008, ISSN 1693-9034.

Scheltema dalam B. Arief Sidharta, Kajian Kefilsafatan tentang Negara Hukum, Jentera (Jurnal Hukum), "Rule of Law", Pusat Studi Hukum dan Kebijakan (PSHK), Jakarta, edisi 3 Tahun II, November 2004. 
Available online at: http://ejournal.unpas.ac.id/index.php/litigasi

Litigasi, Vol. 17(1), 2016, 3221-3255

DOI: http://dx.doi.org/10.23969/litigasi.v17i1.46

\section{WEBSITE}

Bachtiar, 2004, Pengertian Perkawinan Makalah Masalah Tujuan Definisi Perkawinan Menurut Para Ahli, dalam http://www.metrorealita.com/index.php?option $=$ com content\&view $=\mathbf{a}$ rticle\&id $=73$ \& Itemid $=154$.

Jimmly Asshidiqie, Penegakan Hukum, diakses dari www.solusihukum.com, diakses pada tanggal 19 November 2015 jam 14.01 WIB.

Komnasperempuan.or.id/wp-content/uploads/2015/03/Lembar-Fakta-Catatan-

Tahunan-CATAHU-Komnas-Perempuan-Tahun-2014.pdf. diunduh pada Senen 9 November 2015 jam 1.46 WIB.

Mudjiati, Penghapusan Kekerasan dalam Rumah Tangga Suatu Tantangan Menuju Sistem Hukum Yang Responsif Gender, diunduh dari situs www.djpp.depkumham.go.id, diakses 5 April 2013.

Nurherwati, Lemah, Penegakan Hukum Bagi Korban KDRT, http://www.hukumonline.com/berita/baca/It5232b8a2e0623/lemah-penegakan-hukum-bagi-korban-kdrt, diunduh pada Rabu 16 Desember 2015, jam 23.21 WIB.

\section{PERATURAN PERUNDANGAN}

Undang-Undang Dasar 1945.

Kitab Undang-Undang Hukum Pidana (KUHP).

Undang-Undang Nomor 1 Tahun 1974 tentang Perkawinan.

Undang-Undang Nomor 23 tahun 2004 tentang Penghapusan Kekerasan Dalam Rumah Tangga (PKDRT). 